\section{A PROTEÇÃO SOCIAL E O MUNDO DO TRABALHO}

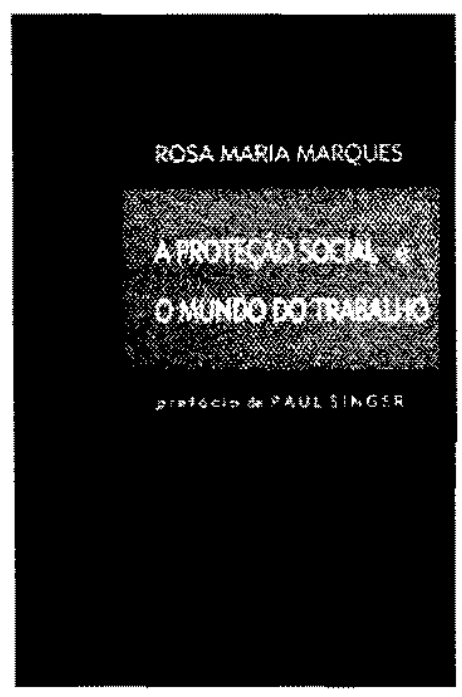

de Rosa Maria Marques

Săo Paulo: Bienal, 1997. 192 p.

por Rosa Maria Vieira, professora do Departamento de Fundamentos Sociais e Juridicos da EAESP/FGV.

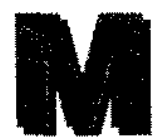

ais um ensaio acadêmico a propósito da crise atual do mundo do trabalho e suas consequências, em que o autor laboriosamente agrupa diferentes concepçôes e abordagens, compondo um bric-à-brac térico, na tentativa de explicar as mudanças em curso no capitalismo contemporâneo? Certamente este não é o caso do livro de Rosa Maria Marques, prefaciado por Paul Singer - A proteçáo social e o mundo do trabalho. Originalmente uma tese de doutorado realizada na Fundação Getulio Vargas de São Paulo, esse estudo reflete a longa experiência de sua autora como economista e pesquisadora da FUNDAP. Alicerçado em largas pesquisas empíricas e dados atualizados, teoricamente amparado nas proposições da escola da regulaçäo, o texto de R. M. Marques analisa as relações mutuamente determinantes entre a crise do sistema de proteção social (Welfare State) e a precariedade do trabalho no mundo globalizado.

Ao tratar a crise do Welfare State e sua relaçäo com o capitalismo no longo ciclo recessivo, tomado por novas tecnologias, financeiramente desregulamentado e no qual as empresas multinacionais conformam novas modalidades de produção oligopolizada, a autora não se exime da polêmica. O leitor interessado no tema encontrará aí o questionamento do termo "globalização", na linha sugerida por François Chesnais ( $A$ mundialização do capital. São Paulo: Xamâ, 1996.), a discussão das propostas de renda mínima, "em substituição ao arranjo institucional que atualmente sustenta a proteção social" (p.14), e de redução da jornada de trabalho. $E$, na parte final, algumas referências ao "caso brasileiro", ou seja, à "formação do sistema de proteçâo social brasileiro, seus problemas atuais, [ao] conteudo da reforma encaminhada pelo governo Fernando Henrique Cardoso e [ao] acordo realizado com as centrais sindicais, como também laol programa de renda mínima garantida, encaminhado pelo senador Eduardo Suplicy (PT/SP)" (p.21-2).

Depois de apontar as circunstâncias históricas de emergência e desenvolvimento dos sistemas de proteção social e destacar seu papel como peçachave no processo de acumulação fordista, a autora analisa o impacto da crise capitalista, instaurada nos anos 70, sobre o mercado de trabalho as formas de produção, redimensionados de modo a recompor as condições favoráveis à geração do lucro. O resultado desse processo é "o mundo do trabalho de pernas para o ar" com uma radical mudança na estrutura de emprego dos países industrializados e na sua capacidade de gerar trabalho (p.59). Ao lado das elevadas taxas de desemprego, observa-se o creseimento da desocupação de longa permanência que atinge especialmente jovens, mutheres e trabalhadores com mais de 40 anos. Em suma, uma nova realidade em que "a ampliação do trabalho a tempo parcial e temporário, onde a regra é a ausência de direitos trabalhistas e sociais" (p.18), e o fantasma da instabilidade passaram a fazer parte das normas do jogo do capital.

Segundo observa R. M. Marques, para esses trabalhadores que vivem a situação de desemprego de 
longa duração não ocorre somente a perda do trabalho. Socialmente excluídos, isto é, desempregados numa sociedade calcada na ética do trabalho produtivo para o capital, esses "desfiliados" vêem-se também desqualificados no plano cívico e político. "Para os que ainda tề a felicidade de estar empregados, parcial ou totalmente, a possibilidade da demissâo ou o fim do contrato determina que vivam somente. o dia de hoje, näo havendo mais, no seu horizonte, o amanha. Nesse quadro de incerteza. o trabalho perde crescentemente sua capacidade de integrar os individuos na sociedade" (p.69).

Qual o impacto dessa nova realidade sobre a ampla rede de proteção social universalizada para o conjunto da população trabalhadora nos países desenvolvidos, a partir da Segunda Guerra Mundial, sob a feição do Welfare State? É na busca de respostas a essa pergunta que a pesquisa se estruturou.

De acordo com a autora, os efeitos imediatos se fizeram sentir sobretudo nos sistemas de proteção social financiados por contribuiçoes. "O crescimento do emprego, junto ao setor de serviço, foi incapaz de gerar massa salarial correspondente à que. da observada junto aos demais setores, particularmente na industria. Esse fato, somado ao crescimento da demanda por beneficios, principalmente àquela derivada de desemprego, aprofundou a fragilidade financeira que os sistemas de proteçâo social já vinham apresentando. De fato, o crescimento anterior da despesa com saúde e aposentadoria, bem como a queda da relação contribuintes/segurados (provocada pelo envelhecimento da população e pela maturidade dos sistemas), já colocavam dificuldades para a maioria dos siste. mas europeus" (p.18).

No quadro atual, largamente desfavorável à classe trabalhadora, acumulam-se os indícios de mudanças radicais no sistema de proteção social, sinalizadas, em particular, pela díscussão corrente sobre a viabilidade ou eficácia da permanência desse sistema. É nesse contexto que ganham vigor e atualidade as propostas de renda mínima em países como França, Dinamarea, Inglaterra, Bélgica, Holanda, Alemanha, entre outros Mas, efetivamente, o que ímplicam esses projetos de renda mínima garantida nos países capitalistas centrais? De que argumentos se valem a direita e a esquerda no debate em torno dessas propostas?

0 livro de R. M. Marques demonstra que as res- postas a essas perguntas passam necessariamente pelo tema da desregulamentação das relações de compra e venda da força de trabalho, pela polêmica em torno da permanência da centralidade do trabalho no mundo contemporâneo e pela problemática da integraçăo social no capitalismo de produção oligopolizada. Nesta medida, encontramos aí, desdobradas, análises da proposta neoliberal de retirada do Estado do mercado de trabalho para que a taxa de desemprego recue ou, ainda, da ética do trabalho como construção histórica do capital, que reconhece tão-somente o labor humano inserido no circuito da acumulação.

Os resultados a que chega esse estudo póem em evidência algumas discussôes essenciais quanto ao futuro do mundo dos que vivem do trabalho. Refiro-me, entre outras, ao questionamento das proposições que, sustentadas numa "leitura estática da atividade capitalista", colocam os niveis atuais de desemprego como naturalmente inevitáveis, desconsiderando "a importância das lutas dos trabalhadores por reduça da jornada na determinação da quantidade de trabalho demandada na economia" (p.101) ou mesmo as possibilidades de um novo ciclo de expansäo. Segundo R. M. Marques, para se "discutir adequadamente a resoluçăo da chamada nova questão social", é necessário "que se retome o debate sobre a reduça da jornada de trabalho". Essa seria "a única via capaz de impe. dir que os ganhos de produtividade inerentes às novas tecnologias sejam unicamente apropriados pelos capitalistas, resultando apenas em desem. prego e baixos salários para os trabalhadores" (p.145).

Para alem de uma polêmica sobre as reais possibilidades da redução da jornada de trabalho propiciar o pleno emprego, é importante alertar quanto aos perigos da idéia de inevitabilidade histórica. Talyez seja essa a mais importante contribuição desse estudo ao lembrar que, no capitalismo, os ganhos de produtividade sempre foram objeto de disputa entre trabalhadores e capitalistas e que, nesse processo, a luta pela diminuição da jornada de trabalho desempenhou papel central. Exclusăo ou formas de sociabilidade que, generosamente, coloquem os homens numa nova relação entre si e com a natureza? As respostas não estăo dadas a priori. Elas serão elaboradas no processo das relações sociais que fazem dos homens os agentes de sua história. 